\title{
SPECIFIC FEATURES OF TEAM KINDS OF SPORTS SPORTSMEN'S INDIVIDUAL CHARACTERISTICS
}

\author{
Liashenko V.N., Tumanova V.N., Hatsko E. V.
}

Kiev University Boris Grinchenko

\begin{abstract}
Purpose: to study individual characteristics of personalities of team kinds of sports sportsmen, specializing in football. Material: in the research football players ( $\mathrm{n}=28$, age $18-20$ years) participated. Psychodiagnostic testing by methodic $16 \mathrm{PF}$ of Kattel was used. Results: we found high correlation between factors, which were conditioned by caution in choosing partners for communication and active contacts. Such sportsmen express their emotions expressively. It facilitates improvement of relations in conditions of co-operation in little group. It was also found that one of personality's leading characteristics in sportsmen is their activity in social contacts. The higher is courage the more active is communication. It promotes discussion of common interests and targets for the given group of people. Conclusions: Sportsmen, who have many emotional interests and are ready to risk (or having bent to adventures) have to face non understanding of other players. In such case conflict can be inevitable. Especially it manifests, if opposite side has the same indicators in this factor. Just courage, risk and adventurism push them to conflict solution of problem situations.
\end{abstract}

Key words: conflictness, expressiveness, conservatism, self-control, team, football.

\section{Introduction}

Any sport team in every kind of sports is a kind of "little" social group [4, 14], the structure of relations in which corresponds to known psychological schemas and pedagogic plan. Success of human activity in social organizations depends on people's consolidation, co-operation, compatibility and conflict-free relations [12, 22, 32, 43]. According to some authors [9, 11, 21, 30], sport team is a special kind of contact community. Team is consolidated by common target of mutual sport activity, the main kinds of which are training and competitions.

It was found that the most typical for sportsmen features of character are: emotional stability, strive for leadership, bent to risk, pragmatism, and inventiveness, and self-control, communicability [25, 26, 35]. In other works [2, 29] authors stress on bent to risk. The authors found that risk is connected with probability of traumas. That is why individual characteristics play great role and reflect dynamic side of a personality. The temper of personality is a complex system of logically interconnected properties with great potentials for inter-compensation of some properties by other. Just correlation of properties determines sportsman's reaction to extreme situation. It was determined that only compensation of "negative" features by "positive" ones can influence on sports functioning [33].

Sport functioning is rather specific in team kinds of sports. It implies solution of current tasks in nonstationary medium. Leading specialists in sports psychology [3, 27] think that in such activity sportsman personality's certain properties will realize. These properties optimize behavior in conflict situations and in struggle with opponent. Therefore, it is necessary to study the most important individual properties of personality for successful competition functioning.

In other studies it was found [27, 28, 31], that efficiency of sport functioning to large extent is determined by personality's individual characteristics. Sportsmen have high aggressiveness, high motivation for achievements, high self-assessment and self-assurance; they also have extraversion and firm character. Operational-functioning characteristics in individual kinds of sports [5, 7] point at sportsmen's high self-assurance, high self-assessment, communicability and expressiveness [8, 10, 19]. However, in game kinds of sports specific of training and competition functioning is different. That is why it is necessary to pay attention to socialpsychological features of a personality, whose influence on results is the most probable exactly in team kinds of sports $[13,15,17]$. That is why, in our work, among sportsmen's multiple and different characteristic features

\footnotetext{
(c) Liashenko V.N., Tumanova V.N.,

Hatsko E. V., Korzh Y.N., 2016

doi:10.15561/20755279.2016.0504
} 
we regarded the following: communicability (demand in communication); credulity-suspiciousness, straightness, conformity (ability to quickly change opinion, under influence of collective pressure), authority (bent to dominate), self-control and discipline [20].

Hypothesis: it was assumed to mark out and study the most significant individual characteristics of sportsmen's personality in team kinds of sports, considering specificity of co-operation for achievement high sport results.

The purpose of the research: to study individual characteristics of personalities of team kinds of sports sportsmen, specializing in football.

\section{Material and methods}

Participants: in the research sportsmen, specializing in football, participated. The age of participants was 18 - 20 years; the quantity -28 persons. When forming the group of sportsmen we considered criterion of uniformity of the tested (variation coefficient did not exceed $10 \%$ ).

Organization of the research: the research took the period of 2013-2014. Psycho-diagnostic testing by methodic 16PF of Kattel was used [18, 34].

Statistical analysis: for every indicator we found mean arithmetic, mean square deviation S (standard deviation) and variation coefficient (V). Sample testing for normality was fulfilled with the help of test $\chi^{2}$. Besides, Pearson's correlation analysis was used. The presence of correlations was considered to be confident at significance level of $\mathrm{p} \leq 0.05 ; 0.01$.

\section{Results of the research}

Sports have distinctive features in comparison with other kinds of activity. Sport is activity, implying overcoming different obstacles. That is why cultivation of sportsman's features is a natural component of sportsman's psychological training.

For determination of football players' tested psychological qualities' significance of priority we conducted correlation analysis between indicators of psychological qualities: «A », «C », «E», «G $»,\langle\mathrm{H} »,\langle\mathrm{I} »,\langle\mathrm{~L} »$, «M», «N», «O», «Q1», «Q2», «Q4», «B», «F».

The highest quantity of correlations was found between factor "H": "shyness-courage" and "F": "carelessness - conflictness".

In our research mean group value of this factor was related to pole of courage and is interpreted as courage in social contacts. This factor positively correlates with conflictness $(\mathrm{r}=0.48)$ as well as with factors: A "communicability" ( $\mathrm{r}=0,42)$; E "obedience - dominance" ( $\mathrm{r}=0.44)$; F "restraint - expressiveness" $(\mathrm{r}=0.70)$; $\mathrm{Q} 1$ "conservatism - radicalism" ( $\mathrm{r}=0.56)$; Q3 "low self-control - high self-control" ( $\mathrm{r}=0.45)$. There is negative correlation with factor M "practicality - daydreaming" $(\mathrm{r}=-0.45), \mathrm{p}<0.05$.

There was also great correlation of factors $\mathrm{H}$ and $\mathrm{A}(\mathrm{r}=0.42)$ : "isolation - communicability". Mean group value by this pole is closer to positive (to communicability). These factors, in the whole, supplement each other.

Sportsmen with expressed communicability are expected to be easy in contacts with partners and in cooperation [23]. Such sportsmen strive for inter-personal contacts, empathize what is happening and expect the same emotions from other people. These sportsmen do not endure "overloading" of communication with many partners. They manage to orient in game situation and in inter-personal contacts.

Sportsmen's communication in game functioning implies situations of "forced co-operation", in which sportsman shall switch in rather active communications with partners. Serious practical problem $[15,16]$ emerges when non communicative sportsman shall support contact with partners and even control their behavior.

Non-coincidence of communicative demands can be also rather a problem for partners' co-operation in team. In such situation one sportsman wants to actively communicate and discuss what is happening. He emotionally responds to what is happening. Other sportsman is irritated by this and distracts from functioning. $\mathrm{He}$ thinks it is unnecessary and excessive. In some cases such differences can result in serious misunderstanding and even conflicts between sportsmen.

In the whole, communicability, openness, easiness in direct inter-personal contacts are characteristics of this factor with positive pole. Their correlation with courage in social contacts is mutually caused. 
The highest correlation was observed between factors $\mathrm{H}$ and $\mathrm{F}-(\mathrm{r}=0.70)$. Factor $\mathrm{F}$ was defined as "restraint- expressiveness". It is emotional expressiveness of personality [44]. It is interesting that with years impulsiveness and carelessness reduce. It can be regarded as an evidence of certain emotional maturity. Mean group value of this factor is " 5 ". It means combining of two poles with correlation with factor "H".

In general factor $\mathrm{F}$ is oriented on measuring of emotional coloring and dynamic in the process of communication. Among tested football players such characteristics as "caution" (reasonability in choosing of partner for communication, bent to worry about future) and cheerfulness (impulsivity, expressiveness, enthusiasm, emotional brightness in communication with other people) are equally blended. Correlation of these factors is evident. On the one hand the sportsmen cautiously choose partners for communication and worry about their future. On the other hand they actively make contacts and expressively show their emotions. It facilitates improvement of relations in conditions of co-operation in little group.

The next correlation is $\mathrm{H}$ and Q1 - $(\mathrm{r}=0.56)$. Here Q1 is «conservatism-radicalism". This factor determines radical, intellectual, political and religious attitude. Mean group value is " 6 ". It is in the center, between two poles of this factor, but closer to "+". In the whole team consists of players with combination of different qualities. They are: conservatism; stable attitude to traditions; bent to moralization and sermons; resistance to changes; orientation on definite real functioning. Other players have opposite qualities: free-thinking; perception of changes and new ideas; distrust in authorities; bent to analytical and theoretical functioning. However, sportsmen with orientation on new prevail. Desire to experiment is encouraged in sports [24, 46].

Optimal combination of the factor's poles permits for sportsmen to communicate with each other. Sportsmen share individual and mutual interests. It permits for them to work successfully in one group.

Moderate correlation is observed between indicators $\mathrm{H}$ and Q3 - $(\mathrm{r}=0.45)$. Here Q3 -is "low self-control - high self-control”. This factor measures internal control of behavior and personality's integration.

People with high values by this factor are bent to organizational activity. They achieve success in professions, where objectiveness, decisiveness and balance are required [20,36, and 38]. This factor characterizes human awareness in regulation of "Self" force (factor C) and "Super-Self" force (factor G). The factor determines expressiveness of personality's will. This factor is one of the most important for prognostication of success. It is positively connected with frequency of leader's election as well as with activity in solution of group problems.

Two poles of this factor are expressed in the following:

- “_“ - low discipline, following own desires; dependence on emotions; inability to control own emotions and behavior;

- "+" - commitment, strong will; ability to control own emotions and behavior.

Mean group value by this factor is " 6 ". It means approaching "+" pole. Low degree of this factor points at weak will and bad self-control. Such people's activity is disordered and impulsive. Person with high values by this factor has socially welcomed characteristics: self-control, insistence, consciousness, bent to follow ethics [37]. To correspond to these standards personality shall have distinct principles, beliefs and consideration of social opinion. This factor is important when solving group problems, characteristic for football team.

Now let us regard negative correlation with this factor: $\mathrm{M}-(\mathrm{r}=-0.45), \mathrm{p}<0.05$, where $\mathrm{M}$ is "Practicality -daydreaming". This factor is rather complex. In general personalities with $\mathrm{M}$ have bright internal intellectual life with intensive feeling of ideas and emotions. In their behavior they can be "Bohemian", non-conforming. High degrees of this factor are intrinsic to artists, poets, researchers, experimenters, managers of high rank, editors. Low degrees are in persons, who deal with monotonous calculations (required attention and concentration). Such persons are characterized by inner balance and reasonability. However, in sudden situations they often feel deficit of imagination and inventiveness. In general this factor is oriented on measuring imagination features, reflecting in personality's actual behavior: practicality; "earthiness", some "head in clouds"; romantic attitude to life.

Mean group value of $\mathrm{M}$ factor is "6". This contingent of sportsmen is characterized by bent to intellectual life and deficit of concentration and attention. For sport collective it is characteristic to all its members in active work on solution of collective tasks. In such group high mutual demands, deep respect to every member exist. In such case personal interests of its members coincide with team's interests [40]. If in the group persons with 
expressed positive pole of this factor prevail there will be no need to seek mutual understanding. In this case inteam life will replace demand in inter-personal relations. It causes difficulties in collective's work on achievement team's targets.

The next factors with the highest quantity of correlations are conflictness - factor $\mathrm{F}$ (restraintexpressiveness); factor E (obedience- dominance); factor Q2) conformism - non-conformism) and factor Q4 "relaxation - tension).

The least quantity of correlations is observed in the following factors: B "intellect"; $\mathrm{N}$ "straightness diplomacy"; O "calmness-anxiety"; G "low normative behavior - high normative behavior"; I "firmness sensitivity"; C "emotional imbalance - emotional balance".

\section{Discussion}

Many authors note that for more effective functioning of sport team it is necessary to know the following: demands and motives of team members; requirements of current situation. Besides, it is necessary to consider such factors as: sportsmen's compatibility in team; identity of thinking; motivation; values' system $[2,15]$. We found that the most developed in football players are such qualities as: courage in social contacts; communicability; expressiveness; conservatism; self-control. In this aspect our results well coincide with other authors' data [10, 12]. For fruitful communication sportsmen shall be prepared for actions in life situations, which would require communicative abilities $[5,14]$.

Self-control is of not less importance for football players [3, 20]. Acquiring and mastering of self-control skills imply general discipline of a person, internal culture and high professional fitness. In this context it is evident that self-control algorithms are fixed under influence of person's self-assessment and his assessment by other people $[1,3,4$, and 13].

It can be assumed that human self-control is included in integral structure of the most important personality's characteristics; self-respect [11,39]. In its integral manifestations, self-control permits to control own behavior and behavior of collective. That is why self-control is an important professional quality for sportsmen of team kinds of sports [30]. In this context team is characterized by inter-personal relations of its members [3]. Between team members non-formal, friendly relations can exist as well as perfect game understanding, worked out by years of training. In such case these relations will serve as the basis of interaction during match $[5,45]$. Emotional feeling of sport situation, expressiveness of sympathy or dislikes, degree of realization of non-formal friendly relations can be a criterion of interaction [11, 41]. Thus, specific of kind of sports or competition exercise requires co-operation from participants and personal contribution into team's success [42]. Specific of team kind of sports also requires interaction of players. The main condition of such interaction will be team's organization and personality's properties of every team member.

\section{Conclusions}

It has been determined that factor $\mathrm{H}$ is one of the main indicators. This factor characterizes degree of activity in social contacts. It reflects organism's activity and features of temper. We think that this factor is of substantial importance in structure of personal characteristics of team kind of sports sportsmen. The more courage sportsman has the more active and communicative he is. It facilitates improvement of contacts in team discussion of mutual interests and targets for the given group of people. With it, it is evident that it has strong correlation with conflictness. Sportsmen with many emotional interests and readiness to risk (or bent to adventurism) have to face misunderstanding of other players. In such case conflict is inevitable. Especially it is possible if other side has the same indicator in this factor. Exactly courage and adventurism push sportsmen to conflict solution of problem situations.

\section{Conflict of interests}

The authors declare that there is no conflict of interests. 


\section{References:}

1. Abramova GS. Obshchaia psikhologiia [General psychology], Moscow: Academic Project; 2003. (in Russian)

2. Barinov VV. Vliianie individual'nykh osobennostej lichnosti basketbolista na uspeshnost' sorevnovatel'noj deiatel'nosti. Kand. Diss. [Influence of individual features of basketball player's personality on success of competition functioning. Cand. Diss.], Moscow; 2001. (in Russian)

3. Bermudes Torres Ankheolina. Osobennosti samokontrolia v processe sorevnovatel'noj deiatel'nosti. Kand. Diss. [On self-control in the process of competition functioning. Cand. Diss.], Leningrad; 1983. (in Russian)

4. Bondarchuk EI. Osnovy psikhologii i pedagogiki [Principles of psychology and pedagogic], Kiev: MAUP; 2001. (in Russian)

5. Vasiura SA. Psikhologiia kommunikativnoj aktivnosti cheloveka [Psychology of human communicative activity], Izhevsk: Udmurt State University; 2006. (in Russian)

6. Vasiura SA. Kommunikativnaia aktivnost' predstavitelej komandnykh i individual'nykh vidov sporta [Communicative activity of representatives of team and individual kinds of sports]. Chelovek. Soobshchestvo. Upravlenie, 2012;2:72 - 81. (in Russian)

7. Gogunov EN, Mart'ianov BI. Psikhologiia fizicheskogo vospitaniia i sporta [Psychology of physical education and sports], Moscow: Academy; 2000. (in Russian)

8. Gordeeva TO, Sychev OA. Vnutrennie istochniki nastojchivosti i ee rol' v uspeshnosti uchebnoj deiatel'nosti [Internal sources of insistence and its role in educational progress]. Psikhologiia obucheniia, 2012;1:33-48. (in Russian)

9. Il'in EP. Psikhologiia sporta [Psychology of sports], Sankt Petersburg: Peter; 2009. (in Russian)

10. Introvert $i$ ekstravert. Enciklopediia prakticheskoj psikhologii «PSIKhOLOGOS» [Introvert and extravert. Encyclopedia of practical psychology "PSYCHOLOGOS"]. [Internet]. 2016 Oct 06 [cited 2016 Oct 06]; Available from: http://www.psychologos.ru/articles/view/introvert_i_ekstravert

11. Zeer EF. Psikhologiia professij [Psychology of professions], Moscow: Academic Project; 2008. (in Russian)

12. Il'in AB. Psikhologicheskij analiz prichin konfliktov v sportivnykh komandakh [Psychological analysis of reasons of conflicts in sport teams]. Sportivnyj psikholog, 2004; 3:27 - 30. (in Russian)

13. Il'in EP. Psikhologiia sporta [Psychology of sports], Sankt Petersburg: Peter; 2016. (in Russian)

14. Ishchenko V, Lisenchuk G, Daragan V. Sravnitel'nyj analiz fizicheskoj podgotovlennosti futbolistov komand raznoj kvalifikacii [Comparative analysis of physical fitness of different qualification teams' football players], Nauka v olimpijskom sporte, 2003;1:50 - 56. (in Russian)

15. Zagajnov R. Psikhologiia sovremennogo sporta vysshikh dostizhenij [Psychology of modern elite sports], Moscow: Soviet sport; 2012. (in Russian)

16. Zagajnov R.M. Psikhologicheskaia atmosfera kak psikhologicheskij fenomen [Psychological atmosphere as psychological phenomenon]. Sportivnyj psikholog, 2005;2:10 - 27. (in Russian)

17. Kardialis K, Aleksandravichiute B. Konfliktnost' i splochennost' sportivnykh komand [Conflictness and consolidation of sport teams]. Psikhologicheskij zhurnal, 2005;26(1):71 - 78. (in Russian)

18. Karelin AA. Bol'shaia enciklopediia psikhologicheskikh testov [Great encyclopedia of psychological tests], Moscow: Eksmo; 2007. (in Russian)

19. Kondrat'ev MIu, Kondrat'ev IuM. Social'no-psikhologicheskij fenomen avtoriteta i otnosheniia avtoritetnosti v gruppe [Social-psychological phenomenon of authority and authority relations in group]. Mir psikhologii, 2006;4:67 - 76. (in Russian)

20. Korableva EV. Ustojchivost' samokontrolia v ekstremal'nykh usloviiakh v sviazi s emocional'no-volevymi osobennostiami lichnosti. Kand. Diss. [Self-control balance in extreme situations in respect to personality's emotional-will characteristics. Cand. Diss.], Moscow; 1993. (in Russian)

21. Krys'ko VG. Social'naia psikhologiia [Social psychology], Moscow: Vlados-Press; 2004. (in Russian)

22. Kuznecov VV. Psikhologicheskij analiz proiavleniia sub"ektno-lichnostnykh svojstv sportsmenov kak pokazatelia uspeshnosti ikh deiatel'nosti. Kand. Diss. [Psychological analysis of sportsmen's subjective- 
personalities qualities' manifestations as indicator of their functioning successfulness. Cand. Diss.], Kazan; 2004. (in Russian)

23. Labunskaia VA. Social'naia psikhologiia obshcheniia kak osnova organizacii peregovorov [Social psychology of communication as a base of negotiations' organization], Rostov on Don: UFU; 2010. (in Russian)

24. Lozhkin GV. Konceptual'nye predstavleniia o psikhologicheskom potenciale kvalificirovannogo sportsmena [Conceptual ideas about elite sportsman's psychological potential]. Nauka v olimpijskom sporte, 2007;1:8793. (in Russian)

25. Lukina TA. Ocenka pokazatelej, kharakterizuiushchikh lichnost' sportsmenov, $i$ ikh dinamika $v$ godichnom makrocikle. Kand. Diss. [Assessment of indicators, characterizing sportsmen's personalities, and their dynamic in annual macro-cycle. Cand. Diss.], Moscow; 1997. (in Russian)

26. Liashenko VM, Tumanova V. Vivchennia psikhologichnikh osoblivostej kvalifikovanikh sportsmeniv [Study of elite sportsmen's psychological characteristics]. Mizhnarodna naukovo-praktichna konferenciia "Fizichna kul'tura i sport u suchasnomu suspil'stvi”, 20 listopada 2015r. [International scientific-practical conference "Physical culture and sports in modern society"< November 20th, 2015], 2015. P. 130-134. (in Ukrainian)

27. Liashenko VN, Tumanova VN, Hatsko EV. Study of personality's temperament and self-assessment of higher educational establishments' students. Physical Education of Students, 2016;20(2):19-23. doi:10.15561/20755279.2016.0203

28. Liashenko VN, Tumanova VN, Mariskina TV. Features of manifestation of self-trained athletes specialized in jumping. Physical Education of Students, 2012;6:70-73.

29. Nogina EV. Kommunikativnaia kompetentnost' kakfaktor uspeshnoj sportivnoj deiatel'nosti regbistok vysokoj kvalifikacii. Kand. Diss. [Communicative competence as a factor of successful sport functioning of elite female rugby players. Cand. Diss.], Malakhovka; 2005. (in Russian)

30. Sopov VF. Teoriia i metodika psikhologicheskoj podgotovki v sovremennom sporte [Theory and methodic of psychological training in modern sports], Moscow; 2010. (in Russian)

31. Tolkunova IV, Liashenko VN. Individual'no - psikhologicheskie razlichiia kvalificirovannykh legkoatletov i ikh vliianie na rezul'tativnost' sorevnovatel'noj deiatel'nosti [Individual psychological distinctions of elite light athletes and their influence on efficiency of competition functioning]. Physical Education of Students, 2009;2:97-100. (in Russian)

32. Khudiakov VP, Kishchenko SE. Psikhologicheskaia podgotovka sportsmenov v komandnykh vidakh sporta $\mathrm{k}$ trenirovochnomu processu i sorevnovaniiu [Psychological preparation of sportsmen for training process and competitions in team kinds of sports]. Innovacionnye proekty i programmy v obrazovanii, 2014;2:57 - 62. (in Russian)

33. Shustikov GB, Fudimov VV. Vliianie sportivnoj deiatel'nosti na formirovanie lichnostnykh kachestv zanimaiushchikhsia [Influence of sport activity on formation of trainees' personality qualities]. Uchenye zapiski universiteta imeni P.F. Lesgafta, 2012;1(83):163-167. (in Russian)

34. Iurov IA. Psikhologicheskoe testirovanie i psikhoterapiia v sporte [Psychological testing and psycho-therapy in sports], Moscow; 2006. (in Russian)

35. Amon AH. Individual strategies of decision under uncertainty. Unpublished doctoral dissertation, University of California: Berkeley; 1962.

36. Anderson CR, Schneier CE. Locus of control, leader behavior and leader performance among management students. Academy of Management Journal, 1978;21:690-698.

37. Zunaira Javed, Soulat Khan, Rukhsana Kausar. Group Cohesion, Decision Making Styles and Group Performance in University Students. Psychological Abstracts, 2012;14:81-82.

38. Hopper C, Fisher B, Munoz KD. Physical activity and nutrition for health. Champaign: Human Kinetics; 2008.

39. Ludovici-Connoly AM. Winning Health Promotion Strategies. Human Kinetics; 2010. 
40. Physical education and sport, healthy lifestyle boosts factors. International scientific session (Bucharest, April 6th 2012). Ministry of education, research, youth and sport. Bucharest: BREN; 2012.

41. Rudenko R, Mahliovanyy A, Shyyan O, Prystupa T. Physical rehabilitation and thermoregulatory processes in athletes with disabilities. Journal of Physical Education and Sport, 2015; 15 (4): 730-735.

42. Ohromiy GV, Makarova NU, Kasyuha AM. Psychophysiological methods and criteria for the selection of individual metered loads in athletes of taekwondo section. Physical Education of Students, 2014;6:54-62. doi: $10.15561 / 20755279.2014 .0611$

43. Schoeneman TJ. Reports of the Sources of Self-knowledge. J. of Personality. 1981;49(3):284-293.

44. Zion LC. Body concepts as it relates to self-concept. Research Quarterly, 1965;1:490-495 p.

45. Sharp RH. Viewing time and occluded time as determined of ball catching success. British Journal of Physical Education, 1974;5(6):22-24.

46. Whitting HTA. An oprerational analysis of a continuous ball throwing and catching task. Ergonomics $1975 ; 13(4) " 445-454$. 


\section{Information about the authors:}

Liashenko V.N.; http://orcid.org/0000-0002-4835-1390; valechka@email.ua; Kiev University Boris Grinchenko; Bulvarno - Kudryavskaya str. 18/2, Kiev, 04053, Ukraine.

Tumanova V.N.; http://orcid.org/0000-0002-9838-6081; v.tumanova@kubg.edu.ua; Kiev University Boris Grinchenko; Bulvarno - Kudryavskaya str. 18/2, Kiev, 04053, Ukraine.

Hatsko E. V.; http://orcid.org/0000-0002-7275-3963; o.hatsko@kubg.edu.ua; Kiev University Boris Grinchenko; Bulvarno - Kudryavskaya str. 18/2, Kiev, 04053, Ukraine.

Korzh Y.N.; http://orcid.org/0000-0003-4363-062X; y.korzh@kubg.edu.ua; Kiev University Boris Grinchenko; Bulvarno - Kudryavskaya str. 18/2, Kiev, 04053, Ukraine.

Cite this article as: Liashenko V.N., Tumanova V.N., Hatsko E. V., Korzh Y.N. Specific features of team kinds of sports sportsmen's individual characteristics. Physical education of students, 2016;5:24-31. doi:10.15561/20755279.2016.0504

The electronic version of this article is the complete one and can be found online at: http://www.sportpedu.org.ua/html/arhive-e.html

This is an Open Access article distributed under the terms of the Creative Commons Attribution License, which permits unrestricted use, distribution, and reproduction in any medium, provided the original work is properly cited (http://creativecommons.org/licenses/by/4.0/deed.en).

Received: 02.10.2016

Accepted: 19.10.2016; Published: 28.10.2016 